
Environmental Effects

\title{
Biochemical conversion of fruit rind of Telfairia occidentalis (fluted pumpkin) and poultry manure
}

\section{Samuel O. Dahunsi, Solomon Oranusi, Vincent E. Efeovbokhan, Soraya} Zahedi, John O. Ojediran, Adeniyi Olayanju, Abimbola P. Oluyori, Timothy A. Adekanye, John O. Izebere \& Munachi Enyinnaya

To cite this article: Samuel O. Dahunsi, Solomon Oranusi, Vincent E. Efeovbokhan, Soraya Zahedi, John O. Ojediran, Adeniyi Olayanju, Abimbola P. Oluyori, Timothy A. Adekanye, John O. Izebere \& Munachi Enyinnaya (2018): Biochemical conversion of fruit rind of Telfairia occidentalis (fluted pumpkin) and poultry manure, Energy Sources, Part A: Recovery, Utilization, and Environmental Effects, DOI: 10.1080/15567036.2018.1511651

To link to this article: https://doi.org/10.1080/15567036.2018.1511651

View supplementary material ¿

\section{Published online: 05 Sep 2018.}

Submit your article to this journal $\square$

\section{山ll Article views: 1}

View Crossmark data $₫$ 


\title{
Biochemical conversion of fruit rind of Telfairia occidentalis (fluted pumpkin) and poultry manure
}

\author{
Samuel O. Dahunsi $\mathbb{1}^{\mathrm{a}}$,b , Solomon Oranusic, Vincent E. Efeovbokhan ${ }^{\mathrm{d}}$, Soraya Zahedi ${ }^{\mathrm{a}, \mathrm{e}}$, \\ John O. Ojediran ${ }^{f}$, Adeniyi Olayanjuf, Abimbola P. Oluyori ${ }^{f}$, Timothy A. Adekanyef, \\ John O. Izebere ${ }^{b}$, and Munachi Enyinnaya ${ }^{a}$
}

\begin{abstract}
aBiomass and Bioenergy Group, Environment and Technology Research Cluster, Landmark University, Omu-Aran, Nigeria; ${ }^{b}$ Biological Sciences Department, Landmark University, Omu-Aran, Nigeria; 'Biological Sciences Department, Covenant University, Ota, Nigeria; ${ }^{\mathrm{d} C h e m i c a l ~ E n g i n e e r i n g ~ D e p a r t m e n t, ~ C o v e n a n t ~ U n i v e r s i t y, ~ O t a, ~ N i g e r i a ; ~}$

'Department of Environmental Technology, Faculty of Marine and Environmental Sciences, Cadiz University, Cadiz, Spain; 'Department of Agricultural and Biosystems Engineering, Landmark University, Omu-Aran, Nigeria; פDepartment of Physical Sciences, Landmark University, Omu-Aran, Nigeria
\end{abstract}

\begin{abstract}
Environmental pollution by solid wastes and inadequate energy supply are some of the major challenges facing the developing world. This study evaluated the potentials of Fluted pumpkin fruit rind and poultry manure for biogas generation. Mechanical and thermo-alkaline pre-treatments were applied to two samples labeled ' $O$ ' and ' $P$ ' while the third sample (Q) had no thermo-alkaline treatment. The physicochemical characteristics of the substrates revealed richness in nutrients and mineral elements. The results showed that use of a combination of pre-treatment methods enhanced the biogas yield in the pre-treated substrates. Analysis of the gas composition showed $66.5 \pm 2.5 \%$ Methane, $25 \pm 1 \%$ Carbon dioxide; $58.5 \pm 2.5 \%$ Methane, $26 \pm 1 \%$ Carbon dioxide; $54.5 \pm 1.5 \%$ Methane, $28 \pm 2 \%$ Carbon dioxide for the three experiments, respectively. All the obtained values show the models had a high predictive ability. The substrates should be further used for energy generation.
\end{abstract}

\section{ARTICLE HISTORY}

Received 9 June 2018

Revised 4 July 2018

Accepted 16 July 2018

\section{KEYWORDS}

Biogas; biomass; methane; microorganisms; pre-treatment; rumen content

\section{Introduction}

Anaerobic digestion $(\mathrm{AD})$ is a veritable way to treat wastes and biomass due to its capacity to reduce greenhouse gas (GHG) emissions by producing clean fuels such as biogas (Dahunsi et al. 2017a, 2017b, 2017c, 2017d). The AD technology for methane generation has been reported to be a more efficient method for energy generation from biomasses in contrast to other biological and thermochemical conversion systems (Zahedi et al. 2016). AD is equally known to be particularly famous in developing countries where mostly the produced gas is used as fuel for cooking while the digestate is used as fertilizer or soil conditioner (Abudi et al. 2016; Dahunsi and Oranusi 2013).

Biogas generation from the mono-fermentation of poultry manure has been extensively reported in energy literature. However, the major challenges encountered were low $\mathrm{C} / \mathrm{N}$ ratio and high total ammonia levels of the substrate (Dalkilic and Ugurlu 2015). It has therefore been opined that for the best digestion and adequate gas yield, poultry dropping is better co-digested with other high energyyielding substrates such as grasses, silage and other green biomasses (Pagliaccia et al. 2016). The advantages of co-digestion over the conventional $\mathrm{AD}$ include adjustment/balances of $\mathrm{C} / \mathrm{N}$ ratio and 
nutrient, $\mathrm{pH}$ buffering capacity increase, decreases in ammonia toxicity, and accumulation of VFAs and upgrading of biochemical conditions for microbial proliferation (Serrano et al. 2016).

Fluted pumpkin (T. occidentalis, Hook. f.) is native to South East Nigeria (Akoroda et al. 1990). It is an important leaf and seed vegetable indigenous to Southern Nigeria and grown in the forest zone of the west and central Africa where it has profound dominance in Nigeria, Ghana, and Sierra Leone (Okoli and Mgbeogwu 1983). It is a member of the family Cucurbitaceae and is a large perennial dioecious plant which climbs by means of bifid and tendrils and usually grows to a height of $20 \mathrm{~m}$ or more. The fruit is a drooping, ellipsoid berry (40 to $95 \mathrm{~cm} \times 20$ to $50 \mathrm{~cm}$ ) usually weighing up to $6 \mathrm{~kg}$, with 10 prominent ribs, pale green and covered with white bloom wax, fruit pulp yellow and many embedded seeds (Eseyin, Sattar, and Rathore 2014). T. occidentalis is majorly cultivated in different agricultural systems majorly for its palatable and nutritious leaves. The leaf is higher in protein content $(\geq 21 \%)$, vitamins and minerals such as Calcium, Phosphorus, and Iron nutritive values than most tropical vegetables (Eseyin, Sattar, and Rathore 2014). Other uses of the leaf include generation of blood parameters due to its hematinic properties while the seed and oil produced from it are also edible (Eseyin, Sattar, and Rathore 2014). However, despite the huge biomass production from the fruit rind of fluted pumpkin, it has remained grossly under-utilized in its different producing localities. It is often thrown into the garbage bin or left in stock piles where they decay and serve as a vehicle for breeding and transmitting disease-causing microorganisms.

The structural and chemical properties of lignocellulosic biomass make them resistant/recalcitrant to anaerobic degradation (Naran, Toor, and Kim 2016) and this factor is also responsible for their limited commercial usage (Menon et al. 2016). Therefore, the application of pretreatment procedures to feedstock before digestion will improve their accessibility to microbial bioconversion (Monlau et al. 2015). Several pretreatment methods have and are still being investigated as a way of combating the initial recalcitrance often encountered in the usage of lignocellulosic biomass.

In some recent studies, alkaline treatment was reported to enhance methane production from the mono-digestion of substrates like sunflower stalks and sorghum forage and from the co-digestion of Carica papayas fruit peels and poultry dropping, T. occidentalis fruit peels and poultry manure, Chromolaena odorata and poultry manure and Arachis hypogaea hulls (Dahunsi et al. 2016a, 2016b). Generally, chemical pretreatments are not suitable for easily biodegradable biomasses due to their higher rate of degradation coupled with production and accumulation of volatile fatty acids (VFA's) which in turn may cause the total failure of methanogenesis. The methods are however very idea for lignocellulosic biomasses due to the complex lignin-cellulose-hemicellulose matrix presents in them (Sambusiti et al. 2013). Usage of combined treatment methods such as thermo-chemical, chemomechanical and others are also widely reported especially in the mono-digestion of sludge from wastewater treatment plants and these helped to improve on the limitations of single pretreatment methods (Naran, Toor, and Kim 2016; Yuan et al. 2016).

The biomass used in this study (T. occidentalis) is novel in biofuel research because to the best of our knowledge, this is the first reported study that established the appropriate pretreatment methods, optimized the important process parameters, and assessed the mass and energy balance of the co-digestion with poultry manure as well as evaluating the economic feasibility of pretreatments (Monlau et al. 2015). Though biogas generation from the mono-digestion of $T$. occidentalis fruit rind has been documented (Dahunsi et al. 2016b), there is a gap in knowledge as the potentials of this biomass for biogas generation in co-digestion alongside the standardization of its process parameters are yet to be reported despite its abundance and year-round availability. This research, therefore, aims at evaluating the anaerobic co-digestion of Telfairia occidentalis rind and poultry manure using different pretreatment methods. The huge biomass production and year-round availability of the biomass is an indication that a permanent usage need be sought for it. Since standardization of parameters is an important step in any biofuel/bioprocess procedure, the optimization of the process parameters, mass, energy, and economic balances (Dahunsi et al. 2017b) was also carried out to establish a benchmark for fluted pumpkin rind's usage as a biogas substrate. 


\section{Materials and methods}

\section{Sample collection and digester description}

Rinds of Telfairia occidentalis were collected from the Staff Quarters of Landmark University, Omu-Aran, Nigeria after the fruits were dissected with knives to separate the seeds and the rind to be used in this study. Fresh poultry manure were also collected from the Landmark University Teaching and Research Farms and transported to the site of the experiment. Bovine rumen content was also collected from the slaughter slab of Landmark University cafeteria and used as inoculums. Since the rind is a lignocellulosic biomass and the need for pretreatment arose, three different methods were employed in order to establish the most appropriate pretreatment method for the digestion of the biomass. The first sample labeled ' $\mathrm{O}$ ' was pretreated using mechanical, thermal, and $\mathrm{NaOH}$-alkaline pretreatment combination earlier described (Dahunsi et al. 2016a, 2016b). To achieve this, a hammer mill was used to crush the biomass severally until a mesh size of $\leq 20 \mathrm{~mm}$ was obtained. The crushed biomass was then thermally treated (By heating) in the Clifton, 88579, Nickel-Electro Ltd., England water bath at $80^{\circ} \mathrm{C}$ for an hour. Prior to choosing the suitable temperature, duration of thermal treatment and quantity of alkali to be used, the Central Composite Design (CCD) was used for the experimental design according to standard method (Dahunsi et al. 2017b, 2017c, 2017d). In the design, a four-factor model was used, i.e. (i) Temperature for thermal pretreatment (ii) Time/duration of thermal pretreatment (iii) Quantity of alkali for alkaline pretreatment (iv) Time/duration for alkaline pretreatment. The pretreatment temperature was varied between $70^{\circ} \mathrm{C}$ and $200^{\circ} \mathrm{C}$ while a pretreatment time between 50 and 80 min was considered. For the quantity of alkali, a variation of $2 \mathrm{~g} / 100 \mathrm{~g}$ TS to $5 \mathrm{~g} / 100 \mathrm{~g}$ TS was used while a time variation of between 18 and $36 \mathrm{~h}$ was used for the alkaline pretreatment.

Immediately following the thermal procedure was alkaline pretreatment with $3 \mathrm{~g} \mathrm{NaOH} / 100 \mathrm{~g}$ TS at $55^{\circ} \mathrm{C}$ for a $24 \mathrm{~h}$ period and at a solid loading of $35 \mathrm{~g} \mathrm{TS} \mathrm{L}^{-1}$. The second sample labeled 'P' was pretreated using the above mechanical and thermal methods but with $\mathrm{KOH}$ alkaline also using $3 \mathrm{~g} \mathrm{KOH} / 100 \mathrm{~g}$ TS at $55^{\circ} \mathrm{C}$ for a $24 \mathrm{~h}$. The choice of $\mathrm{NaOH}$ and $\mathrm{KOH}$ was premised on earlier reports that among other widely used alkalis, they produced the best result for thermo-alkaline pretreatment ( $\mathrm{Li}$, Champagne, and Anderson 2015). The third sample ' $Q$ ' was treated mechanically but without thermal and alkaline pretreatment and served as control. The twenty five-liter volume digesters already described (Alfa et al. 2014a) were employed in this study. The digester's tank was made airtight with an inbuilt mechanical stirrer to accommodate for adequate substrate mixing and microorganism's distribution while gas collection was done by liquid displacement (Alfa et al. 2014b).

\section{Methane potential tests}

In order to determine the potential methane production of the substrates at STP, the biomethane potential test was carried out following already prescribed methods (Dahunsi et al. 2016a, 2016b). The experiment ran anaerobically in a batch system for 30 days using two digesters for the experiment and a blank making three in all and in triplicate with inoculums to substrate ratio of 2. Collection of produced gas from the digesters was constantly carried out and the methane content was analyzed chromatographically. The same method was employed for carrying out the Residual methane test carried out on the solid digestates (Yap et al. 2016).

\section{Digestion}

The digestion processes were carried out for the three samples of $T$. occidentalis fruit rind in addition with poultry manure. Since dilution of feedstock is a necessary step to eliminating ammonia inhibition during digestion (Sun et al. 2016), T. occidentalis fruit rind and poultry manure were mixed with water to form slurry at a solid loading of $35 \mathrm{~g} \mathrm{TS} \mathrm{L}^{-1}$ and was introduced into each digester tank through an inlet pipe (Alfa et al. 2014a). This was carried out for each of the pretreated sample of T. occidentalis fruit rind and poultry manure. To each of 
the preparation was added one $\mathrm{kg}$ rumen content used as inoculums prior to loading. In each case, the entire 17 liters slurry occupied three-quarter of the digester space thereby leaving an empty space for gas collection. Several parameters were evaluated at different times of the anaerobic digestion process to ensure treatment efficiency. Such includes daily measurement of gas production, evaluation of microbial succession at different stages of the digestion process and weekly analysis of feedstock and effluent. Temperature measurement was done twice daily and the average value taken. $\mathrm{pH}$ measurement was done weekly using $\mathrm{pH}$ meter model $\mathrm{pHS}-2 \mathrm{~S}$, (SHANGHAI JINYKE REX, CHINA) and the average of 3 replicates was computed. The methane and other contents of the generated biogas were determined using a Gas Chromatography (GC) (HP 5890, Avondale, USA) coupled with a Hayesep Q column (13 m x $0.5 \mathrm{~m} \mathrm{x} \mathrm{1/800)} \mathrm{and} \mathrm{a}$ flame ionization detector (FID) (Alfa et al. 2014b).

\section{Analytical procedures}

Substrates for anaerobic digestion must be adequately characterized prior to digestion (Lalak et al. 2016). With this fact in mind, all the samples of T. occidentalis fruit rind, the poultry manure, and inoculums were analyzed in order to quantify their important physical and chemical parameters. These analyses were also carried out on the digestates at the end of the digestions. The analyses were done in the Environmental Engineering laboratory (Civil Engineering Department), Landmark University, Omu-Aran, Nigeria. Prior analyses, centrifugation was carried out in order to separate the liquid from the solid portion in each sample and the latter was used for all analyses except those of total phenol. All the chemical parameters were evaluated in triplicates using the Palintest ${ }^{(\mathrm{R})}$ Photometer 7500 (PHOT.1.1.AUTO.75) advanced digital-readout colorimeter (Camlad, Cambridge, United Kingdom) which was operated at 0.5 absorbance and $450 \mathrm{~nm}$ wavelength as earlier described (Dahunsi et al., 2016a, 2016b). These parameters include Total Carbon, Total Nitrogen (TN), Total Phosphorus (TP), Phosphates $\left(\mathrm{PO}_{4}\right)$, Sulfates $\left(\mathrm{SO}_{4}\right)$ Potassium $(\mathrm{K})$, Sodium $(\mathrm{Na})$, Magnesium $(\mathrm{Mg})$, Calcium $(\mathrm{Ca})$, Nitrates $\left(\mathrm{NO}_{3}\right)$, Ammonium $\left(\mathrm{NH}_{4}\right)$, Iron $(\mathrm{Fe})$, Copper $(\mathrm{Cu})$, Zinc (Zn), Aluminum (Al) and Manganese (Mn). The American Public Health Association, (2012) standard methods for the examination of water and wastewater subsequently used by Dahunsi et al. (2014) was used to determine the Chemical Oxygen Demand (COD) of all samples. Determination of total solids (TS) and volatile solids (VS) were done using the SFS 3008 protocol of the Finnish Standard Association, (1990). For TS, samples were dried at $105^{\circ} \mathrm{C}$ until constant weight was achieved while for VS, known weights of the dried samples were ignited at $575 \pm 25^{\circ} \mathrm{C}$ to constant weight. A microtube test (Spectroquant, Merck) closely followed by a 4 -aminoantipyrine colorimetric measurement was used for total phenolic contents determination (Monlau et al. 2015). A mild acid hydrolysis protocol with further quantification by the anthrone method was used for soluble sugars, i.e., sucrose and inulin extraction (Monlau et al. 2012). For the quantification of structural carbohydrates, i.e., glucose, xylose, and arabinose and uronic acids, i.e., galacturonic and glucuronic acids, a strong acid hydrolysis protocol (Monlau et al. 2015) was used. In determining the lignin content of the samples, $100 \mathrm{mg}$ dried samples were hydrolyzed with $12 \mathrm{M} \mathrm{H}_{2} \mathrm{SO}_{4}$ for $1 \mathrm{~h}$ at room temperature. The solution was then diluted to reach a $1.5 \mathrm{M}$ final acid concentration and was kept at $100^{\circ} \mathrm{C}$ for $2 \mathrm{~h}$ before centrifuging at $10000 \mathrm{rpm}$ for $10 \mathrm{~min}$. The Klason lignin content was thereafter determined as the weight of the residue. The monomeric sugar content of the samples was used for cellulose and hemicelluloses content determination as follows:

$$
\begin{gathered}
\text { Cellulose }(\% \mathrm{DW})=\frac{\text { Glucose }(\% \mathrm{DW})}{1.11} \\
\text { Hemicelluloses }(\% \mathrm{DW})=\frac{\text { Xylose }(\% \mathrm{DW})+\text { Arabinose }(\% \mathrm{DW})}{1.13}
\end{gathered}
$$


where 1.11 stands for the conversion factor for glucose-based polymers to monomers and 1.13 is the conversion factor for xylose-based polymers to monomers (Baraket et al. 2015).

\section{Preliminary energy balance and assessment of thermo-alkaline pretreatment efficiency}

There is a need to justify the investment into the thermo-alkaline pretreatment applied in this study. In doing this, an assessment was carried out to compare the energy generation and consumption. The cost of obtaining heat energy and alkalis $(\mathrm{NaOH}$ and $\mathrm{KOH})$ was compared with the gain accrued from the sale of the additional energy obtained when thermo-alkaline pretreatments were applied to experiments ' $\mathrm{O}$ ' and ' $\mathrm{P}$ '. This helped to determine if the gain from the sale of the extra gas (Obtained from the digestion of the pretreated substrates) was enough to cover the initial expenses on heat energy and alkalis. A simple computational equation was used to first determine the thermal energy required (TER) in $\mathrm{kWh} \mathrm{t}^{-1} \mathrm{TS}$ for raising the temperature of one ton TS of T. occidentalis fruit rind from $25^{\circ} \mathrm{C}$ to $55^{\circ} \mathrm{C}$ during pretreatment. The equation is shown thus:

$$
\mathrm{TER}=\frac{m \times S h *(\text { Qfinal }- \text { Qinitial })}{3600}
$$

where $m(1000 \mathrm{~kg})=$ mass of the mixture of $T$. occidentalis fruit rind and water $(\mathrm{kg}) ; \mathrm{Sh}=$ specific heat of water, i.e., $4.18 \mathrm{~kJ} \mathrm{~kg}^{-1} \mathrm{C}^{-1}$; $Q$ initial $\left({ }^{\circ} \mathrm{C}\right)$ is the initial temperature of substrate, i.e., $25 ; \mathrm{Q}$ final $\left({ }^{\circ} \mathrm{C}\right)$ is the final temperature of substrate, i.e., 55. The United States cost of $\mathrm{NaOH}$ and $\mathrm{KOH}$ were used.

\section{Statistical data analysis}

The test of significance and analysis of variance (ANOVA) were used to analyze all data obtained which was further confirmed by Duncan Multiple Range Test.

\section{Results}

\section{The effects of thermo-alkaline pretreatment on the chemical composition of $T$. occidentalis fruit peels}

The results of the structural parameters analyses carried out on the raw T. occidentalis fruit peels, the thermo-alkaline pretreated and the untreated substrates used in the digestion process are shown in Table 1. In both thermo-alkaline pretreated samples, i.e., ' $\mathrm{O}$ ' and ' $\mathrm{P}$ ', pronounced solubilization of cellulose, hemicelluloses, and klason lignin were reported compared to sample ' $Q$ ' which had no thermo-alkaline pretreatment. After the pretreatments, there were $56 \%$ and $43 \%$ reduction in cellulose concentration for experiments ' $\mathrm{O}$ ' and 'P', respectively. For hemicelluloses, the observed reductions were $47 \%$ and $32.28 \%$ while for klason lignin concentration, reductions of $36 \%$ and $29 \%$ were reported, respectively. There were changes in the concentrations of uronic acids as reductions of 51.4 and 36.25 were reported, respectively. For the concentration of soluble sugars, there were increases of $68.03 \%$ and $65.18 \%$ as a result of the pronounced solubilization due to the application of thermo-alkaline pretreatment to fruit peels of $T$. occidentalis. Overall, higher solubilization of components was reported in experiment 'O' as against ' $\mathrm{P}$ '.

\section{Anaerobic digestion performance and stability}

In the residual methane test, biogas production commenced on the 3rd, 4th and 7 th experimental days of the experiments for digestions ' $\mathrm{O}$ ', ' $\mathrm{P}$ ' and ' $\mathrm{Q}$ ' and the average estimated methane content of the biogas ranged from $64 \%$ to $68 \%, 58 \%$ to $61 \%$, and $53 \%$ to $58 \%$ respectively. Table 1 further shows the result of the physical and chemical analysis of samples of T. occidentalis fruit rind and poultry 


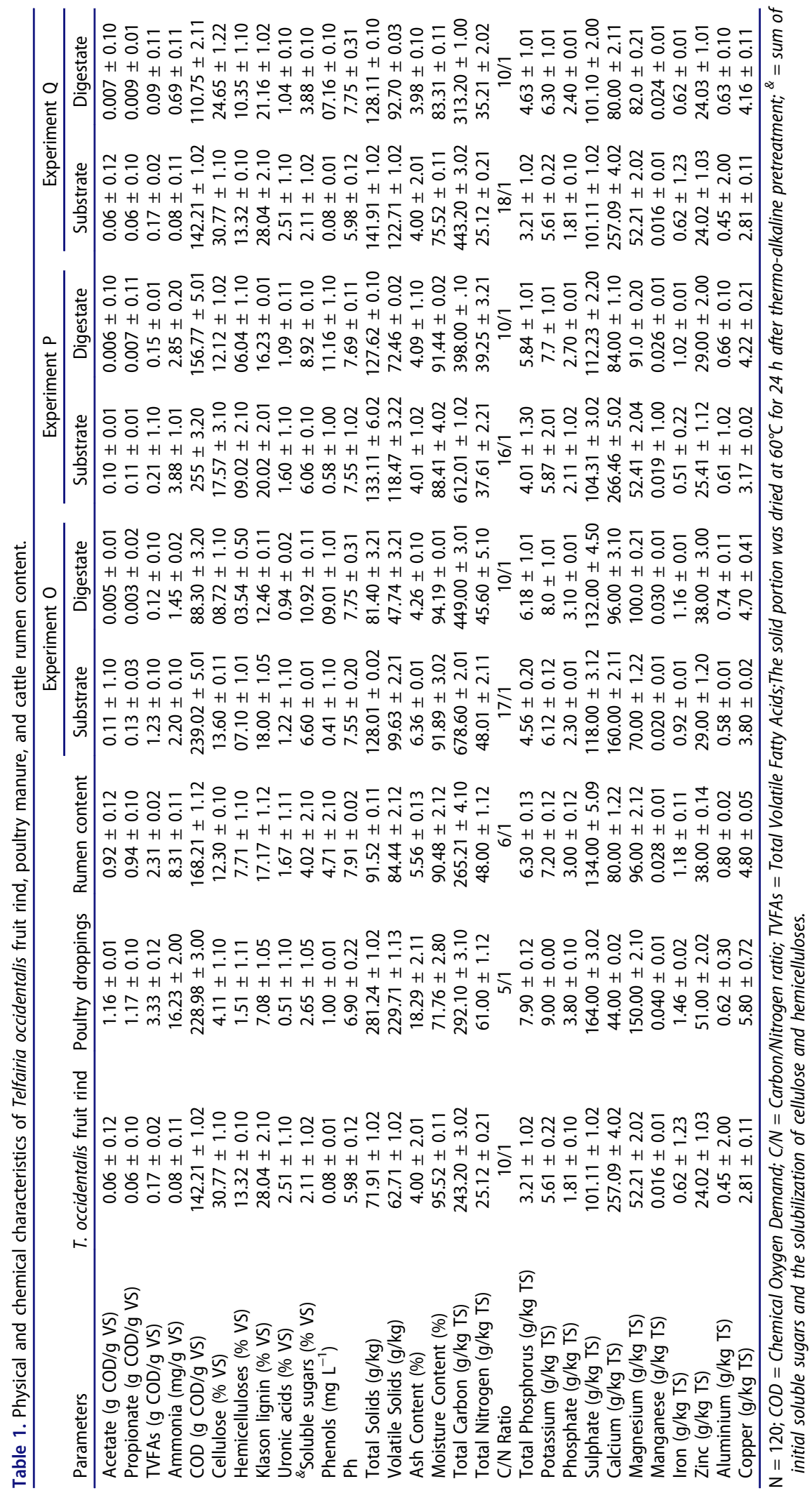




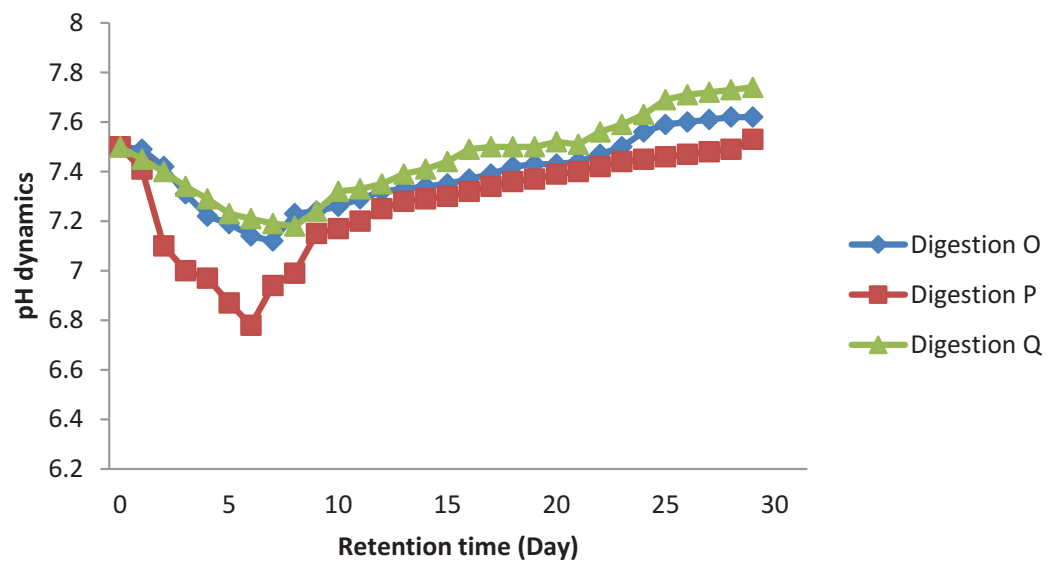

Figure 1. pH fluctuations during the anarobic digestion of Telfairia occidentalisfruit rind and poultry manure (Digestions $\mathrm{O}, \mathrm{P}$, and $\mathrm{Q}$ ).

manure prior to and after digestion and that of the inoculums used. At the end of the digestion of the three samples, further solubilization of structural components of the biomass was recorded. In experiment ' $\mathrm{O}$ ', there were $36 \%, 50.14 \%, 31 \%, 23 \%$, and $95.44 \%$ decrease in the values of cellulose, hemicelluloses, klason lignin, uronic acids, and phenol while the soluble sugar content increased by $40 \%$ at the end of the anaerobic digestion. For experiment ' $\mathrm{P}$ ', the record shows $31 \%, 33.03 \%, 19 \%$, $32 \%$, and $95 \%$ decrease in the values of cellulose, hemicelluloses, klason lignin, uronic acids, and phenol while the increase in soluble sugar content was by $32.06 \%$. Similarly, for experiment ' $Q$ ', there was $20 \%, 22.29 \%, 25 \%, 59 \%$, and $99 \%$ decrease in the values of cellulose, hemicelluloses, klason lignin, uronic acids, and phenol while soluble sugar content increased by $46 \%$ after the digestion. The $\mathrm{pH}$ of the substrate in all the setups was slightly alkaline throughout the anaerobic digestion process (Figure 1) thus falling within the experimental design range (6.5 to 8) by Response Surface. Also, the temperature of all the digesters remained within the mesophilic range $\left(30^{\circ} \mathrm{C}\right.$ to $\left.40^{\circ} \mathrm{C}\right)$ throughout the experiment according to the experimental design. The result of chemical analyses showed that after the digestion of the substrates, there were increase in values for ash content, moisture content, total Nitrogen, total Phosphorus, Potassium, Sulfate, Phosphate, Magnesium, Manganese, Iron, Zinc, Aluminium, and Copper while values recorded for other parameters were reduced in digestions ' $\mathrm{O}$ ', ' $\mathrm{P}$ ' and ' $\mathrm{Q}$ '. The table equally revealed that the mixtures of $T$. occidentalis fruit peels and inoculums were lighter than the rumen content alone in terms of total and volatile solids. The average values of COD for the three digestates were significantly reduced from that of the original substrates $(67.29 \%, 62.21 \%$, and $59.72 \%$ reduction for digestions 'O', 'P' and 'Q', respectively) at the end of the digestion period. The raw T. occidentalis fruit rind recorded low $\mathrm{C} / \mathrm{N}$ ratio with a value of $10 / 1$ whereas samples ' $O$ ', 'P' and 'Q' had values of $17 / 1$ and 16/1 and 18/1, respectively.

\section{Optimization of pretreatment and biogas generation}

According to the experimental design used for the thermo-alkaline pretreatment procedure in this study, the optimal condition for the treatment was: temperature of $80^{\circ} \mathrm{C}$, thermal treatment duration of $60 \mathrm{~min}$, alkali concentration of $3 \mathrm{~g} / 100 \mathrm{~g}$ TS and alkaline treatment for $24 \mathrm{hr}$. Among all the tested experimental runs, the above-stated condition gave the highest biogas yield of $1659.9010^{-3} \mathrm{~m}^{3} / \mathrm{kg} \mathrm{VS}$ in the mono-digestion of Telfairia occidentalis fruit rind as shown in Table 2. Biogas generation in all the experiments commenced from between 2 nd to 4 th, 5 th to 7 th and 7 th to 9 th experimental days in digestions ' $\mathrm{O}$ ', ' $\mathrm{P}$ ' and ' $\mathrm{Q}$ ' until between the 17th and 26th day in most cases before decreasing till 
Table 2. Experimental design of Telfairia occidentalis fruit rind's pretreatment prior to digestion.

\begin{tabular}{|c|c|c|c|c|c|c|}
\hline Sample & $\begin{array}{l}\text { Pretreatment } \\
\text { temperature } \\
\left({ }^{\mathrm{O}} \mathrm{C}\right)\end{array}$ & $\begin{array}{l}\text { Pretreatment } \\
\text { time (Min) }\end{array}$ & $\begin{array}{l}\text { Quantity of } \\
\text { alkali for } \\
\text { pretreatment } \\
\text { (g/100 g TS) }\end{array}$ & $\begin{array}{l}\text { Time/ } \\
\text { duration for } \\
\text { pretreatment } \\
\text { (h) }\end{array}$ & $\begin{array}{c}\text { Biogas Produced from } \\
\text { mono-digestion of } \\
\text { Telfairia occidentalis } \\
\text { fruit rind } \\
\left(10^{-3} \mathrm{~m}^{3} / \mathrm{kg} \mathrm{VS}\right) \\
\text { (Dahunsi et al. 2016b) }\end{array}$ & $\begin{array}{l}\text { Biogas Produced from co- } \\
\text { digestion of Telfairia } \\
\text { occidentalis fruit rind and } \\
\text { poultry manure } \\
\left(10^{-3} \mathrm{~m}^{3} / \mathrm{kg} \mathrm{VS}\right)\end{array}$ \\
\hline UTO & 0 & 0 & 0 & 0 & 1003.30 & 2134.06 \\
\hline $\mathrm{TO}_{70,70}$ & 70 & 70 & 2 & 24 & 1166.22 & 2237.31 \\
\hline $\mathrm{TO}_{80,60}$ & 80 & 60 & 3 & 24 & 1659.90 & 2614.14 \\
\hline $\mathrm{TO}_{90,60}$ & 90 & 70 & 3 & 28 & 1622.17 & 2600.20 \\
\hline $\mathrm{TO}_{100,60}$ & 100 & 60 & 5 & 32 & 1592.12 & 2543.12 \\
\hline $\mathrm{TO}_{110,60}$ & 110 & 70 & 3.5 & 30 & 1561.13 & 2403.31 \\
\hline $\mathrm{TO}_{120,60}$ & 120 & 60 & 2.5 & 26 & 1432.36 & 2231.11 \\
\hline $\mathrm{TO}_{130,50}$ & 130 & 50 & 4 & 24 & 1575.23 & 2163.05 \\
\hline $\mathrm{TO}_{140,70}$ & 140 & 70 & 4.5 & 24 & 1483.26 & 2231.91 \\
\hline $\mathrm{TO}_{150,50}$ & 150 & 50 & 5 & 28 & 1323.24 & 2521.51 \\
\hline $\mathrm{TO}_{160,70}$ & 160 & 70 & 4 & 34 & 1149.24 & 2145.55 \\
\hline $\mathrm{TO}_{70,50}$ & 170 & 50 & 3 & 36 & 1509.21 & 2311.11 \\
\hline $\mathrm{TO}_{180,50}$ & 180 & 50 & 3.5 & 28 & 1199.21 & 2401.11 \\
\hline $\mathrm{TO}_{190,60}$ & 190 & 60 & 2.5 & 36 & 1581.70 & 2090.00 \\
\hline $\mathrm{TO}_{200,50}$ & 200 & 50 & 3 & 30 & 1600.03 & 2311.04 \\
\hline
\end{tabular}

Note: $T O=$ Telfairia occidentalis; UTO = Untreated Telfairia occidentalis

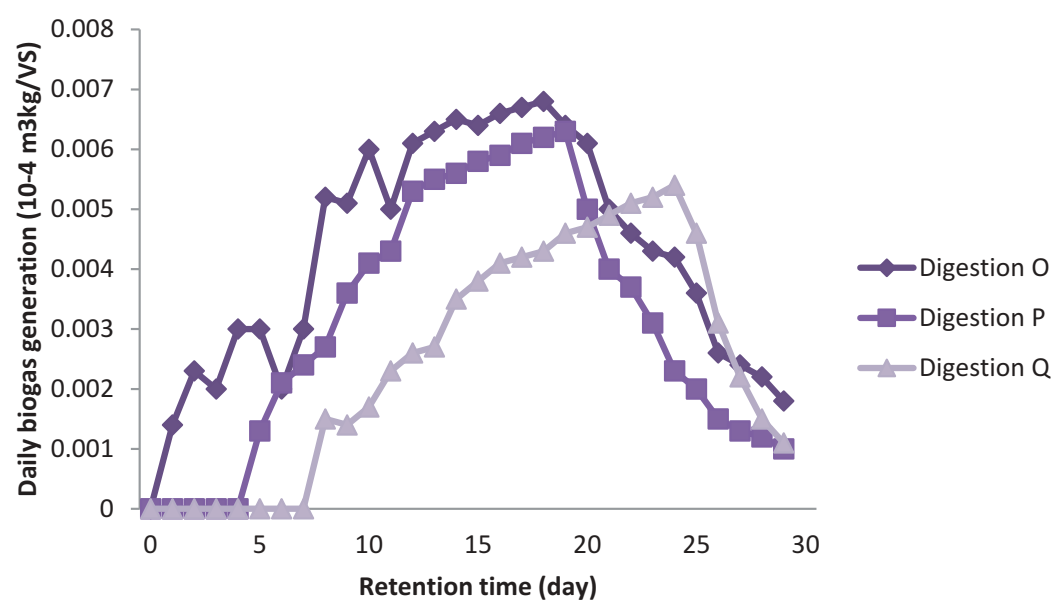

Figure 2. Average biogas generation during the anarobic digestion of Telfairia occidentalisfruit rind and poultry manure (Digestions $\mathrm{O}, \mathrm{P}$, and Q).

the end of the experiments (Figure 2). Gas chromatography analysis revealed the gas composition to be within the range of $66.5 \pm 2.5 \%$ Methane and $25 \pm 1 \%$ Carbon dioxide for digestion 'O'; $58.5 \pm 2.5 \%$ Methane and $26 \pm 1 \%$ Carbon dioxide for digestion ' $\mathrm{P}$ ' and $54.5 \pm 1.5 \%$ Methane and $28 \pm 2 \%$ Carbon dioxide for digestion ' $Q$ ', respectively.

\section{Stoichiometry and mass balance}

The mass balances of all the digested samples of T. occidentalis fruit rind and poultry manure in terms of volatile VS degradation are shown in table S1 (Supplementary materials). In computing the mass balance, "T. occidentalis fruit peels" was considered to be the input variable while the trio of "methane", "carbon dioxide", and "the anaerobic digestate" were the output variables. In all three digestions, mass balances of 39, 31, and 12 were recorded. Also, experiments 'O' and 'P' had 69.23\% 
and $61.29 \%$ higher mass balance than experiment 'Q'. In terms of VS degradation, the three experiments recorded VS reduction of $51 \%, 41 \%$, and $21 \%$ respectively. Also, there were 59 and 49 higher VS removal in experiments 'O' and 'P', respectively, over 'Q'.

\section{Discussion}

As seen in this study, the use of mechanical grinding, thermal, and alkaline (NaOH and $\mathrm{KOH})$ for pretreatment brought about enormous solubilization/degradation of all tested structural components of the biomass ( $T$. occidentalis fruit peels) which is a major advancement over previous studies. Another novel finding is about the optimized conditions obtained via the CCD which contributed to the breakdown of these structural materials and the subsequent high biogas yield obtained especially in the thermo-alkaline treated samples. Cellulose and hemicellulose breakdown as a result of thermoalkaline pretreatment (steam explosion, dilute acids, ammonia fiber expansion, ionic liquids, thermal, thermo-alkaline, alkaline thermo-mechanical, and the fenton process) applications is well reported in literature and such treatments usually led to higher biogas yield (Mahdy, Ballesteros, and González-Fernández 2016; Mustafa, Poulsen, and Sheng 2016). Similarly, lignin solubilization as a result of pretreatment application to different biomasses has been reported. Notable is the work of Naran, Toor, and Kim (2016) where high lignin breakdown was reported when $\mathrm{NaOH}$ alkalinethermal treatment was applied. Similar results have been obtained from other studies (Monlau et al. 2015; Sambusiti et al. 2013). Another major observation caused by the application of thermo-alkaline pretreatments in this study was the higher soluble sugar yield in the pretreated experiments and this compares favorably with the results of Monlau et al. (2015). These sugars are beneficial to acidogenic and hydrolytic bacteria who utilize them during substrate degradation and this usually boosts microbial population, activities as well as diversity. When these happen, intermediate acids are produced serving as raw materials for the subsequent acetogenesis and methanogenesis stages of digestion. Production of phenols was another evidence of structural breakdown in this study and this is further evident in the concentrations of these compounds recorded in experiments ' $\mathrm{O}$ ' and ' $\mathrm{P}$ '. Such a trend has been reported with the application of alkaline pretreatment (Dahunsi et al. 2017a, 2017c). The 17 and $16 \mathrm{C} / \mathrm{N}$ ratios obtained for experiments ' $\mathrm{O}$ ' and ' $\mathrm{P}$ ' after pretreatment further confirms the potency of the method for treating the biomass and this agrees with the $17 \mathrm{C} / \mathrm{N}$ obtained by Degueurce et al. (2016) from the digestion of spent cow beddings.

Throughout the digestion period, the $\mathrm{pH}$ of all the digestions in ' $\mathrm{O}$ ', ' $\mathrm{P}$ ' and ' $\mathrm{Q}$ ' remained at a slightly alkaline range. This is in tandem with previous reports which state that the suitable $\mathrm{pH}$ for the most efficient methanogenesis is between 6.5 and 8 (Dahunsi et al. 2016a, 2016b). A pH range of less than 6.5 or higher than 8 is known to cause failure of the anaerobic process (Dahunsi et al., 2016a). Therefore, the maintenance of suitable $\mathrm{pH}$ in anaerobic digesters is fundamental to ensure adequate bioconversion (Zahedi et al. 2016). In the same vein, the temperature of the digesters in 'O', ' $\mathrm{P}$ ' and ' $\mathrm{Q}$ ' remained at the mesophilic range throughout the experiment. Temperature is an important factor in anaerobiosis since the various arrays of bacteria involved in the bioconversion of substrate are known to operate at optimal temperature (Jain et al. 2015). Besides, the mesophilic temperature adopted in this study ensures better stability of digestion besides providing the needed condition for bacteria proliferation and efficiency (Mao et al. 2015).

All the three samples of Telfairia occidentalis fruit rind used in this study were revealed to be enormously rich in nutrients and basic minerals required for microbial growth and subsequent substrate degradation in a fermentation process as shown by the physicochemical analysis. The nutrient status of the three anaerobic digestates were found to be higher after the various digestion compared to the levels prior to digestion with digestion ' $\mathrm{O}$ ' being the highest followed by ' $\mathrm{P}$ ' and ' $\mathrm{Q}$ ' was the least. The values of most major (Nitrogen, Phosphorus and Potassium) and minor (Magnesium, Manganese, Iron, Zinc, Aluminum, and Copper) elements all increased. This indicates the usefulness of the digestates as efficient fertilizers for increasing soil fertility and enhancement of crop yield. The usage of anaerobic digestate as biofertilizers or soil conditioners has been advocated 
in several studies (Alfa et al. 2013a, 2013b; Pivato et al. 2016). In this study, the anaerobic digestion was very efficient in COD removal; higher reduction value than in some previous anaerobic digestions (Alfa et al. 2014b) was obtained. Biogas generated in digestion 'O' was highest and followed by ' $\mathrm{P}$ ' while ' $\mathrm{Q}$ ' produced the least quantity and methane content. The highest gas yield in digestion ' $\mathrm{O}$ ' could be attributed to the combination of mechanical, thermal, and $\mathrm{NaOH}$ alkaline pretreatment methods which posed more positive effects in the substrate degradation than the $\mathrm{KOH}$ pretreatment in digestion ' $\mathrm{P}$ ' and this was also better than experiment ' $\mathrm{Q}$ ' which had mechanical treatment only. As earlier proposed therefore, application of combinations of pretreatment methods is a promising alternative to achieving biomass degradation and higher biogas generation (Mathews, Grunden, and Pawlak 2016; Menon et al. 2016). This already reflected in the results of the stoichiometry and mass balance in this study which shows pronounced substrate interactions and VS consumption which was highest in experiment ' $\mathrm{O}$ ' followed by ' $\mathrm{P}$ ' and then ' $\mathrm{Q}$ '.

The combined heat and power (CHP) system was employed to evaluate the energy balance as well as the economic feasibility of thermo-alkaline pretreatment application to T. occidentalis fruit rind. In doing this, a 50\% thermal efficiency and 35\% electrical efficiency was adopted as shown in table S2 (Supplementary materials). In using this system, the possibility that the profit obtained from the sale of the extra thermal and electrical energies will be sufficient to replenish the cost of procuring heat for thermal pretreatment and chemicals $(\mathrm{NaOH}$ and $\mathrm{KOH})$ used for the alkaline pretreatment. In determining the TER for thermo-alkaline pretreatment of T. occidentalis fruit peels therefore, the energy needed to raise the temperature of $35 \mathrm{~g} \mathrm{TS} \mathrm{L}^{-1} \mathrm{~T}$. occidentalis fruit peels mixture from $25^{\circ} \mathrm{C}$ to $55^{\circ} \mathrm{C}$ was determined using $4.18 \mathrm{~kJ} \mathrm{~kg}^{-1 \mathrm{o}} \mathrm{C}^{-1}$ as the specific heat of water in order to evaluate the specific heat of the mixture while heat loss was neglected (Zupancic and Ros 2003). The result shows that for experiment ' $\mathrm{O}$ ', the $1147 \mathrm{kWh} \mathrm{t}^{-1}$ TS thermal energy gain at a solid loading of $35 \mathrm{~g} \mathrm{TS} \mathrm{L}^{-1}$ was higher than the TER for the thermo-alkaline pretreatment which was $1088 \mathrm{kWh} \mathrm{t}^{-1}$ TS when heat and $\mathrm{NaOH}$ were used. For experiment ' $\mathrm{P}$ ' the thermal energy gain of $1049 \mathrm{kWh} \mathrm{t}^{-1}$ TS was lower than the TER of $1109 \mathrm{kWh} \mathrm{t}^{-1}$ TS needed for pretreatment using heat and $\mathrm{KOH}$. Earlier researches have proposed the use of heat exchanger during digester heating and/or biomass pretreatment as a way of boosting up to $80 \%$ heat recovery (Dahar et al. 2012).

For the electrical energy assessment, only the electric energy used for the substrate mixing was considered while the energy used during mechanical grinding was neglected since this was also done for experiment ' $Q$ ' which had no thermo-alkaline pretreatment (Menardo, Airoldi, and Balsari 2012). The result shows that the estimated net electrical energies at a solid loading of $35 \mathrm{~g} \mathrm{TS} \mathrm{L}^{-1}$ was $430 \mathrm{kWh} \mathrm{t}^{-1}$ TS and $223 \mathrm{kWh} \mathrm{t}^{-1}$ TS for experiments ' $\mathrm{O}$ ' and ' $\mathrm{P}$ ', respectively. The possibility of injecting these energies into the energy grid or being sold for a fixed cost is high as this will generate extra income and also compensate for the resources used for the pretreatment. In accounting for the economic value of the used alkalis, the 335 and 100 dollars ton ${ }^{-1}$ US cost of $\mathrm{NaOH}$ and $\mathrm{KOH}$ were used.

\section{Conclusion}

T. occidentalis is well adapted to several geographical locations especially in the tropics. Richness of the combination of the rind and poultry manure in terms of minerals and elemental composition suggest that it is suitable for biofuel and biofertilizer production. It was clearly revealed that the use of mechanical and thermo-chemical pretreatment produced higher biogas quantity and methane content as well as higher mass, energy and economic balances. Further usage of T. occidentalis fruit rind and poultry manure as energy feedstock is therefore proposed.

\section{Acknowledgments}

Authors are grateful to our Laboratory staffs who assisted in carrying out parts of the work. We are equally grateful to our final year students for their numerous contributions to the success of this research. 


\section{Conflict of interest}

Authors declare that there is no conflict of interest whatsoever.

\section{Funding}

This work was supported by the Landmark University, Nigeria [LU10433];

\section{ORCID}

Samuel O. Dahunsi (D) http://orcid.org/0000-0003-3088-1577

\section{References}

Abudi, Z. N., Z. Hu, N. Sun, B. Xiao, N. Raja, C. Liu, and D. Guo. 2016. Batch anaerobic co-digestion of OFMSW (organic fraction of municipal solid waste), TWAS (thickened waste activated sludge) and RS (rice straw): Influence of TWAS and RS pretreatment and mixing ratio. Energy 107:131-40. doi:10.1016/j.energy.2016.03.141.

Akoroda, M. O., N. I. Ogbechie-Odiaka, M. L. Adebayo, O. E. Ugwo, and B. Fuwa. 1990. Flowering, pollination and fruiting in fluted pumpkin (Telfairia occidentalis). Scientia Horticulturae 43:197-206. doi:10.1016/0304-4238(90) 90091-R.

Alfa, I. M., D. B. Adie, S. B. Igboro, U. S. Oranusi, S. O. Dahunsi, and D. M. Akali. 2014a. Assessment of biofertilizer quality and health implications of anaerobic digestion effluent of cow dung and chicken droppings. Renewable Energy 63:681-86.

Alfa, I. M., D. B. Adie, O. T. Iorhemen, C. C. Okafor, S. A. Ajayi, and S. O. Dahunsi. 2013a. Assesment of mesophilic co-digestion of cow dung with lemon grass for biogas production. Nigerian Journal of Technology 32 (3):478-84.

Alfa, I. M., S. O. Dahunsi, O. T. Iorhemen, C. C. Okafor, and S. A. Ajayi. 2014b. Comparative evaluation of biogas production from poultry droppings, cow dung and lemon grass. Bioresource Technology 157:270-77. doi:10.1016/j. biortech.2014.01.108.

Alfa, I. M., J. A. Otun, S. B. Igboro, S. O. Dahunsi, S. A. Ajayi, and D. M. Akali. 2013b. Between and betwixt soil fertility improvement and disease transmission: An assessment of the suitability of anaerobic digestion effluent for direct application as fertilizer. Nigerian Journal of Technology 32 (3):492-97.

APHA. 2012. Standard methods for examination of water and waste-water. $22^{\text {nd }}$ ed. Washington DC: American Public Health Association.

Barakat, A., F. Monlau, A. Solhy, and H. Carrere. 2015. Mechanical dissociation and fragmentation of lignocellulosic biomass: Effect of initial moisture, biochemical and structural proprieties on energy requirement. Applied Energy 142:240-46. doi:10.1016/j.apenergy.2014.12.076.

Dahunsi, S. O., S. Oranusi, and V. E. Efeovbokhan. 2017a. Bioconversion of Tithonia diversifolia (Mexican Sunflower) and poultry droppings for energy generation: Optimization, mass and energy balances, and economic benefits. Energy and Fuels 31:5145-5157. doi:10.1021/acs.energyfuels.7b00148.

Dahunsi, S. O., S. Oranusi, and V. E. Efeovbokhan. 2017b. Cleaner energy for cleaner production: Modeling and optimization of biogas generation from Carica papayas (Pawpaw) fruit peels. Journal of Cleaner Production 156:1929. doi:10.1016/j.jclepro.2017.04.042.

Dahunsi, S. O., S. Oranusi, and V. E. Efeovbokhan. 2017c. Optimization of pretreatment, process performance, mass and energy balance in the anaerobic digestion of Arachis hypogaea (Peanut) hull. Energy Conversion and Management 139:260-75. doi:10.1016/j.enconman.2017.02.063.

Dahunsi, S. O., S. Oranusi, J. B. Owolabi, and V. E. Efeovbokhan. 2017d. Synergy of Siam weed (Chromolaena odorata) and poultry manure for energy generation: Effects of pretreatment methods, modeling and process optimization. Bioresource Technology 225:409-17. doi:10.1016/j.biortech.2016.11.123.

Dahunsi, S. O., S. Oranusi, J. B. Owolabi, and V. E. Efeovbokhan. 2016a. Mesophilic anaerobic co-digestion of poultry droppings and Carica papaya peels: Modelling and process parameter optimization study. Bioresource Technology 216:587-600. doi:10.1016/j.biortech.2016.05.118.

Dahunsi, S. O., S. Oranusi, J. B. Owolabi, and V. E. Efeovbokhan. 2016b. Comparative biogas generation from fruit peels of fluted pumpkin (Telfairia occidentalis) and its optimization. Bioresource Technology 221:517-25. doi:10.1016/j.biortech.2016.09.065.

Dahunsi, S. O., S. Oranusi, J. B. Owolabi, and V. E. Efeovbokhan. 2017. Synergy of Siam weed (Chromolaena odorata) and poultry manure for energy generation: Effects of pretreatment methods, modeling and process optimization. Bioresource Technology 225:409-17. doi:10.1016/j.biortech.2016.11.123. 
Dahunsi, S. O., and U. S. Oranusi. 2013. Co-digestion of food waste and human excreta for biogas production. British Biotechnology Journal 3 (4):485-99. doi:10.9734/BBJ/2013/4476.

Dahunsi, S. O., H. I. Owamah, T. A. Ayandiran, and S. U. Oranusi. 2014. Drinking water quality and public health of selected towns in South Western Nigeria. Water Quality Exposure and Health 6:143-53. doi:10.1007/s12403-0140118-6.

Dalkılıc, K., and A. Ugurlu. 2015. Biogas production from chicken manure at different organic loading rates in a mesophilic-thermopilic two stage anaerobic system. Journal of Bioscience and Bioengineering 120 (3):315-22. doi:10.1016/j.jbiosc.2015.01.021.

Degueurce, A., N. Tomas, S. Le Roux, J. Martinez, and P. Peu. 2016. Biotic and abiotic roles of leachate recirculation in batch mode solid-state anaerobic digestion of cattle manure. Bioresource Technology 200:388-95. doi:10.1016/j. biortech.2015.10.060.

Dhar, B. R., G. Nakhla, and M. B. Ray. 2012. Techno-economic evaluation of ultrasound and thermal pretreatments for enhanced anaerobic digestion of municipal waste activated sludge. Waste Management 32:542-49. doi:10.1016/j. wasman.2011.10.007.

Eseyin, O. A., M. A. Sattar, and H. A. Rathore. 2014. A review of the pharmacological and biological activities of the aerial parts of Telfairia occidentalis Hook.f. (Cucurbitaceae). Tropical Journal of Pharmaceutical Research 13 (10):1761-69.

Finnish Standard Association SFS 3008 (1990). Determination of total residue and total fixed residue in water, sludge and sediment, 1990. doi:10.1099/00221287-136-2-327.

Jain, S., S. Jain, I. T. Wolf, J. Lee, and Y. W. Tong. 2015. A comprehensive review on operating parameters and different pretreatment methodologies for anaerobic digestion of municipal solid waste. Renewable and Sustainable Energy Review 52:142-54. doi:10.1016/j.rser.2015.07.091.

Lalak, J., A. Kasprzycka, D. Martyniak, and J. Tys. 2016. Effect of biological pretreatment of Agropyron elongatum 'BAMAR' on biogas production by anaerobic digestion. Bioresource Technology 200:194-200. doi:10.1016/j. biortech.2015.10.022.

Li, C., P. Champagne, and B. C. Anderson. 2015. Enhanced biogas production from anaerobic co-digestion of municipal wastewater treatment sludge and fat, oil and grease (FOG) by a modified two-stage thermophilic digester system with selected thermo-chemical pre-treatment. Renewable Energy 83:474-82. doi:10.1016/j. renene.2015.04.055.

Mahdy, A., M. Ballesteros, and C. González-Fernández. 2016. Enzymatic pretreatment of Chlorella vulgaris for biogas production: Influence of urban wastewater as a sole nutrient source on macromolecular profile and biocatalyst efficiency. Bioresource Technology 199:319-25. doi:10.1016/j.biortech.2015.08.080.

Mao, C., Y. Feng, X. Wang, and G. Ren. 2015. Review on research achievement of biogas from anaerobic digestion. Renewable and Sustainable Energy Review 45:540-55. doi:10.1016/j.rser.2015.02.032.

Mathews, S. L., A. M. Grunden, and J. Pawlak. 2016. Degradation of lignocellulose and lignin by Paenibacillus glucanolyticus. International Biodeterioration and Biodegradation 110:79-86. doi:10.1016/j.ibiod.2016.02.012.

Menardo, S., G. Airoldi, and P. Balsari. 2012. The effect of particle size and thermal pretreatment on the methane yield of four agricultural by-products. Bioresourc Technology 104:708-14. doi:10.1016/j.biortech.2011.10.061.

Menon, A., F. Ren, J. Y. Wang, and A. Giannis. 2016. Effect of pretreatment techniques on food waste solubilization and biogas production during thermophilic batch anaerobic digestion. Journal of Materials Cycles and Waste Management 18:222-30. doi:10.1007/s10163-015-0395-6.

Monlau, F., A. Barakat, J. P. Steyer, and H. Carrere. 2012. Comparison of seven types of thermo-chemical pretreatment on the structural features and anaerobic digestion of sunflower stalks. Bioresource Technology 120:241-47. doi:10.1016/j.biortech.2012.06.018.

Monlau, F., C. Sambusiti, N. Antoniou, A. Barakat, and A. Zabaniotou. 2015. A new concept for enhancing energy recovery from agricultural residues by coupling anaerobic digestion and pyrolysis process. Applied Energy 148:3238. doi:10.1016/j.apenergy.2015.03.024.

Mustafa, A. M., T. G. Poulsen, and K. Sheng. 2016. Fungal pretreatment of rice straw with Pleurotus ostreatus and Trichoderma reesei to enhance methane production under solid-state anaerobic digestion. Applied Energy 180:66171. doi:10.1016/j.apenergy.2016.07.135.

Naran, E., U. A. Toor, and D. Kim. 2016. Effect of pretreatment and anaerobic co-digestion of food waste and waste activated sludge on stabilization and methane production. International Biodeterioration and Biodegradation 113:17-21. doi:10.1016/j.ibiod.2016.04.011.

Okoli, B. E., and C. M. Mgbeogwu. 1983. Fluted pumpkin, Telfairia occidentalis: West African vegetable crop. Economic Botany 37 (2):145-47. doi:10.1007/BF02858775.

Pagliaccia, P., A. Gallipoli, A. Gianico, D. Montecchio, and C. M. Braguglia. 2016. Single stage anaerobic bioconversion of food waste in mono and co-digestion with olive husks: Impact of thermal pretreatment on hydrogen and methane production. International Journal of Hydrogen Energy 41:905-15. doi:10.1016/j. ijhydene.2015.10.061. 
Pivato, A., S. Vanin, R. Raga, M. C. Lavagnolo, A. Barausse, A. Rieple, A. Laurent, and R. Cossu. 2016. Use of digestate from a decentralized on-farm biogas plant as fertilizer in soils: An ecotoxicological study for future indicators in risk and life cycle assessment. Waste Management. doi:10.1016/j.wasman.2015.12.009.

Sambusiti, C., E. Ficara, F. Malpei, J. P. Steyer, and H. Carrere. 2013. Benefit of sodium hydroxide pretreatment of ensiled sorghum forage on the anaerobic reactor stability and methane production. Bioresource Technology 144:149-55. doi:10.1016/j.biortech.2013.06.095.

Serrano, A., J. A. Siles, M. A. Martín, A. F. Chica, F. S. Estevez-Pastor, and E. Toro-Baptista. 2016. Improvement of anaerobic digestion of sewage sludge through microwave pre-treatment. Journal of Environmental Management 177:231-39. doi:10.1016/j.jenvman.2016.03.048.

Sun, C., W. Cao, C. J. Banks, S. Heaven, and R. Liu. 2016. Biogas production from undiluted chicken manure and maize silage: A study of ammonia inhibition in high solids anaerobic digestion. Bioresource Technology 218:121523. doi:10.1016/j.biortech.2016.07.082.

Yap, S. D., S. Astals, P. D. Jensen, D. J. Batstone, and S. Tait. 2016. Pilot-scale testing of a leachbed for anaerobic digestion of livestock residues on-farm. Waste Management 2016. doi:10.1016/j.wasman.2016.02.031.

Yuan, H., B. Yu, P. Cheng, N. Zhu, C. Yin, and L. Ying. 2016. Pilot-scale study of enhanced anaerobic digestion of waste activated sludge by electrochemical and sodium hypochlorite combination pretreatment. International Biodeterioration and Biodegradation 110:227-34. doi:10.1016/j.ibiod.2016.04.001.

Zahedi, S., R. Solera, F. Micolucci, C. Cavinato, and D. Bolzonella. 2016. Changes in microbial community during hydrogen and methane production in two-stage thermophilic anaerobic co-digestion process from biowaste. Waste Management 49:40-46. doi:10.1016/j.wasman.2016.01.016.

Zupancic, G. D., and M. Ros. 2003. Heat and energy requirements in thermophilic anaerobic sludge digestion. Renewable Energy 28:2255-67. doi:10.1016/S0960-1481(03)00134-4. 